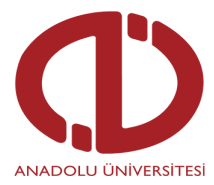

Açıköğretim Uygulamaları ve Araştırmaları Dergisi AUAd

https://dergipark.org.tr/tr/pub/auad

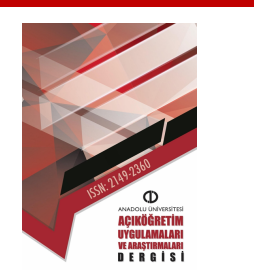

Gönderim: 26.11.2021

Düzeltme: 22.01 .2022

Kabul: 31.01 .2022

Tür: Araştırma Makalesi

\title{
Tartışma forumlarının açık ve uzaktan öğrenme ortamlarında kullanılabilirliği ve bir ölçme-değerlendirme kriteri olarak değerlendirilmesi
}

\author{
Hakan KILINÇ \\ a Anadolu Üniversitesi, Açıöğretim Fakültesi, Uzaktan Eğitim Anabilim Dalı, ORCID: 0000-0002-4301-1370
}

\begin{abstract}
Özet
Gerçekleştirilen bu çalışmada, çevrimiçi tartışma forumlarının açık ve uzaktan öğrenme ortamlarında etkili bir şekilde nasıl kullanılabileceğini belirlemek ve bir ölçme-değerlendirme kriteri olarak nasıl değerlendirilmesi gerektiğini ortaya çıkarmak amaçlanmıştır. Bu kapsamda açık ve uzaktan öğrenme alanındaki uzmanların görüşlerini elde etmek amacıyla durum çalışması deseni kullanılmıştır. Veri toplama aracı olarak yapılandırılmış görüşme formunun kullanıldığı bu araştırmada, katılımcıların belirlenmesinde amaçlı örnekleme yöntemlerinden biri olan ölçüt örnekleme kullanılmıştır. Ölçüt olarak, katılımcıların açık ve uzaktan öğrenme alanında uzman olmaları göz önünde bulundurulmuştur. Bu kapsamda dokuz alan uzmanı çalışmaya katkı sağlamıştır. Çalışma sonunda elde edilen sonuçlar, tartışma forumlarında oyunlaştırma ögelerine yer vermek, tartışma sürecini yönetebilmek, katılımcıları iş birliğine teşvik etmek, akıllı sistemleri kullanmak, kullanıcı dostu ara yüz tasarlamak, duyarlı (responsive) tasarımlara yer vermek, süreç değerlendirme yaklaşımı benimsemek yönünde olmuştur. Çalışma sonunda, elde edilen bulgulardan yola çıkarak; çevrimiçi tartışma forumlarında rütbe vermek, en fazla katkı sağlayanları belirlemek gibi oyunlaştırıcı ögelere yer verilmesi, kitlesel gruplar için akıllı sistemlerin kullanılması, kullanıcı dostu duyarlı tasarımlar kullanılması, süreç değerlendirme yaklaşımının benimsenmesi gibi önerilerde bulunulmuştur.
\end{abstract}

Anahtar Sözcükler: Çevrimiçi öğrenme, çevrimiçi tartışma forumları, açık ve uzak öğrenme, durum çalışması.

\section{Usability of discussion forums in open and distance learning environments and evaluation as a measurement-evaluation criterion}

\begin{abstract}
In this study, it is aimed to determine how online discussion forums can be used effectively in open and distance learning environments and to reveal how they should be evaluated as a measurement-evaluation criterion. In this context, a case study design was used to obtain the opinions of experts in the field of open and distance learning. In this study, in which a structured interview form was used as a data collection tool, criterion sampling was used to determine the participants. As a criterion, it was taken into account that the participants were experts in the field of open and distance learning. In this context, nine field experts contributed to the study. The results obtained at the end of the study were to include gamification elements in discussion forums, to manage the discussion process, to encourage the participants to cooperate, to use smart systems, to design a user-friendly interface, to include responsive designs, and to adopt a process evaluation approach. At the end of the study, some suggestions were made based on the findings obtained.
\end{abstract}

Keywords: Online learning, online discussion forums, open and distance learning, case study. 


\section{Giriş}

Çevrimiçi öğrenme ortamları; öğrenme materyallerine erişme, içerik, öğretici ve öğrenenler ile etkileşme; öğrenme sürecinde öğrenene destek olma, bilgiyi elde etmek için kişisel anlamı yapılandırma ve öğrenme deneyimini arttırma olarak tanımlanabilecek olan çevrimiçi öğrenmenin gerçekleştirilmesine olanak veren internet tabanlı ortamlardır. Çevrimiçi öğrenme ortamlarının eşzamanlı ve eşzamansız iletişim, içerik yönetimi, yönetimsel konular, değerlendirme, öğrenen-öğretici-içerik arasındaki etkileşim gibi boyutlarda eğitimsel düzenlemeler içermesi gerekmektedir (Hrastinski, 2006). Bununla birlikte, Van Alten, Phielix, Janssen ve Kester (2019) öğrenme çıktılarını belirlemenin etkili bir öğrenme ortamı oluşturmak açısından önemine vurgu yapmış ve eğer öğrenme materyalleri ve öğrenme çıktıları açıkça ve kapsamlı olarak tanımlanmışsa iyi bir öğrenme sistemi inşa etmenin daha kolay olacağını ifade etmiştir. Çevrimiçi öğrenme ortamlarının metin tabanlı veya görsel tabanlı olmaları gibi yapısal özelliklerinin yanında dayandığı kuramsal temeller ve eğitimsel düzenlemeler de öğrenme ortamlarının daha etkili ve verimli olması için önemlidir. Bu noktada, en çok vurgu yapılan konulardan birinin de çevrimiçi öğrenme ortamlarında gerçekleştirilen etkileşimler olduğu ifade edilebilir.

Öğrenme ortamlarında gerçekleşen etkileşimler, daha zengin öğrenme çıktılarına ulaşabilme noktasında oldukça önem taşımaktadır. Vygotsky (1967)'e göre toplumsal ve bilişsel gelişme, ilk olarak öğrenen ve öğretici etkileşimlerinin olduğu toplumsal düzlemde gerçeklemekte; bu aşamadan sonra toplumsal içerik ve bağlam, bireysel düzleme dönüştürülerek içselleştirilmektedir. Bu süreçte gerçekleştirilen diyaloglar ile birlikte görüş ve düşüncelerin açıklığa kavuşturulması, ayrıntılandırılması, savunulması ve bütünleştirilmesi gibi bilişsel süreçler işlerlik kazanmaktadır (Jonassen vd., 1995). Bir başka deyişle anlamın oluşturulması ya da bilginin yapılandırılması, düşünceler dile getirildiği, yansıtıldığı ve tartışıldığı sürece gerçekleşmektedir. Geleneksel ortamda sözlü olarak gerçekleşen bu iletişim süreci, çevrimiçi ortamların yaygınlaşması ile yazılı biçimde de yapılabilmektedir. Çevrimiçi öğrenme ortamlarında sağlanan yazılı iletişim imkânı, bu ortamlarda gerçekleştirilen iletişim sürecinin eş zamansız bir şekilde gerçekleştirilmesini sağlamaktadır.

Eş-zamansız iletişim, özellikle uzaktan eğitimde en çok kullanılan ve en yararlı olan iletişim türüdür (Kalelioğlu ve Deryakulu, 2011). Eş zamansız iletişim ile birlikte, çevrimiçi öğrenme ortamlarında öğrenenlerin bilgi alışverişinde bulunmalarına, yaratıcı fikirler geliştirmelerine, daha iyi bir anlayış oluşturmalarına ve öğrenme sürecine daha etkileşimli bir şekilde katılmalarına izin veren çevrimiçi grup tartışması tekniğinin (Knowlton, 2002) uygulanmasına olanak sağlanmaktadır. Çevrimiçi öğrenme ortamlarında gerçekleştirilen grup 
tartışmaları, e-posta, tartışma forumları, konferans sistemleri, Wiki'ler ve diğer Web 2.0 teknolojileriyle gerçekleştirilebilmektedir (Black vd., 2011; Gilbert ve Dabbagh, 2005). Çevrimiçi grup tartışması sürecinde kullanılan araçlar arasında daha fazla özelliğe sahip olan tartışma forumları (Schiek ve Ullrich, 2019) bu süreçte en fazla tercih edilen öğrenme arac1 olmaktadır. Çevrimiçi öğrenme ortamlarında öğrenenlerin öğrenme sürecinde tartışmaları ve etkileşime girmeleri istenmektedir (Loncar vd., 2014). İlkokuldan üniversiteye kadar öğretenler, geleneksel yüz yüze öğrenme durumlarında her zaman etkili olmayan etkileşimi ve karmaşık düşünceyi teşvik etmek için çoğunlukla çevrimiçi tartışma forumlarını kullanmaktadırlar (Chen ve Wang, 2009). Öğrenenlerin, fikirlerini diğer öğrenenlere yansıtarak keşfedici öğrenmeye olanak tanıyan diyaloglar oluşturabilmelerini sağlayan tartışma forumları (Hampton vd., 2017), çevrimiçi öğrenme ortamında öğrenenlerin eş zamanlı veya eş zamansız olarak bilgi oluşturma, iş birliği içinde olma ve etkileşimde bulunmalarını sağlayan bir araçtır (So, 2009). Gerosa vd. (2010), çevrimiçi tartışma forumunu, daha iyi öğrenebilmek için kullanılan eş zamansız bir metinsel iletişim aracı olarak tanımlamaktadır. Çevrimiçi tartışma forumları, kendine güveni daha az seviyede olan öğrenenlere düşüncelerini dile getirme konusunda yardımcı olurken, diğer taraftan da tüm öğrenenlere kendi fikirlerini yansıtmaları ve öğrenme sürecindeki diğer öğrenenlere yanıt vermeleri konusunda daha fazla zaman tanımaktadır (Kılınç, 2020).

Öğrenenin katılımını, iş birliğini ve daha derin öğrenmeyi teşvik etmek için çevrimiçi öğrenme süreçlerinde yaygın olarak kullanılan araçlardan biri olan çevrimiçi tartışma forumlarının (Lyons ve Evans, 2013) daha verimli olabilmesi için Hew ve Cheung (2008) tarafından şu yedi bileşenin altı çizilmiştir. Bu bileşenler;

- kendi görüşlerini veya deneyimlerini sunmak,

- soru sormak,

- takdir göstermek,

- tartışmalara zemin oluşturmak,

- tartışmalara yeni bir yön önermek,

- insanları kişisel olarak katkıda bulunmaya davet etmek,

- süreç içinde gerçekleşen tartışmaları özetlemek,

şeklindedir. $\mathrm{Bu}$ noktada, çevrimiçi tartışma forumlarında gerçekleştirilen öğrenme etkinliklerinde öğreticilerin bu unsurlara dikkat etmesi gerektiği ifade edilebilir.

Çevrimiçi öğrenme ortamlarında öğrenenlerin işbiliğine dayalı bir şekilde birbirleriyle etkileşime geçmelerine olanak tanıyan tartışma forumları gibi öğrenme araçlarını kullanmanın yanı sıra öğrenme sürecinden alınacak olan verimi artıran bu araçların ölçme-değerlendirme 
süreçlerinde de değerlendirilmesi, üzerine durulması gereken başka bir konu olarak değerlendirilmektedir.

\section{Çevrimiçi Öğrenme Ortamlarında Ölçme-Değerlendirme Uygulamaları}

Açık ve uzaktan eğitimde ölçme ve değerlendirme türlerine ilişkin alanyazında farklı sınıflandırmalar ile karşılaşılmaktadır. Bu kapsamda en yaygın sınıflandırma, öğrenme etkinlikleri sürerken yapılan biçimlendirme (yetiştirme) amaçlı değerlendirme (formative assessment) ve öğrenme etkinlikleri sonunda gerçekleştirilen düzey belirleme (değer biçme) amaçlı yapılan değerlendirme (summative assessment) şeklindedir (Karadağ, 2016). Chaudhary (2013)'e göre, biçimlendirme (yetiştirme) amaçlı değerlendirme, çalışma materyallerinde verilen değerlendirme dışı etkinlikleri ve geribildirimleri, öğrencilerin gelişimlerini izlemelerine olanak sağlayan öz-değerlendirme testlerini, ödevlerden, akranlardan ya da öğreticilerden alınan geribildirimleri, öğretici ya da diğer öğrencilerle olan etkileşimi ve öğrencileri sınavlara hazırlayan testleri içermektedir. Düzey belirleme (değer biçme) amaçlı değerlendirme ise gözetimli dönem sonu sınavlarını, başarı notuna etki eden ödevleri ya da performans sınavlarını içermektedir. Düzey belirleme amaçlı değerlendirmenin temel amacı, öğrencilerin başarı durumlarını kayıt altına almak ve raporlaştırmaktır (Simonson, Smaldino, Albright ve Zvacek, 2012).

Simonson vd. (2012), açık ve uzaktan öğrenmede biçimlendirme amaçlı değerlendirme ve düzey belirleme amaçlı değerlendirmenin yanında objektif ve subjektif değerlendirme biçimlerinin de olduğunu belirtmiştir. Buna göre objektif ve subjektif değerlendirme, öğrencilerin başarısını ölçmede kullanılan araçların özellikleriyle ilgiliyken, biçimlendirme ve düzey belirleme amaçlı değerlendirme ölçme sonuçlarının nasıl kullanılacağıyla ilgilidir. Açık ve uzaktan öğrenmede objektif testler; önemli sınırlılıkları olmasına karşın, uygulama ve değerlendirmenin kolay olması, öğrenme/ders yönetim sistemlerinde kullanılabilmesi, bireyselleştirilebilmesi, kişiye uyarlanabilmesi, bilgisayarla notlandırılabilmesi ve anında geribildirim verilebilmesi açılarından avantaj sağlamaktadır. Çoktan seçmeli testler objektif testlere en iyi örnektir. Buna karşılık, araştırma makalesi, proje, çevrim içi tartışmalar, eportfolyo, kavram haritası gibi ölçme araç ve teknikleri otantik ve performansa dayalı değerlendirme açısından olanak sağlasa da subjektif değerlendirmeye yol açabilecek araçlardır.

Karadağ (2016)'a göre, açık ve uzaktan eğitimde öğrencileri değerlendirmede kullanılan biçimlendirme ve düzey belirleme amaçlı değerlendirmede objektif ve subjektif değerlendirmedeki ölçme araç ve teknikleri kullanılabilir. Bununla birlikte, biçimlendirme amaçlı değerlendirmede kullanılacak araç ve teknikler hem öğreticinin hem de öğrencilerin 
öğrenim süreci boyunca gelişimlerini izlemelerini sağlayacak şekilde ve sürekli geribildirim yoluyla öğrenme yaşantılarını zenginleştirecek biçimde tasarlanmalıdır. Bu noktadan hareketle, çevrim içi tartışmaların gerçekleştirildiği tartışma forumlarının biçimlendirme amaçlı değerlendirme bağlamında kullanılabilecek önemli bir araç olduğu ifade edilebilir. Bununla birlikte, tartışma forumlarının bir ölçme değerlendirme aracı olarak kullanılabilmesi noktasında hangi noktalara dikkat edilmesi gerektiği ve nasıl bir tasarımla işe koşulması gerektiği, cevaplanması gereken bir durum olduğu ifade edilebilir.

\section{Çalışmanın önemi}

Loncar vd. (2014) tarafından gerçekleştirilen çalışmada, çevrimiçi öğrenme ortamlarında yüz yüze iletişimin olmaması nedeniyle ilerleyen zamanlarda bu ortamlarda çevrimiçi tartışma forumlarının daha fazla kullanılacağı ifade edilmiştir. Bunun yanı sıra de Lima, Gerosa, Conte ve Netto (2019) ve Green vd. (2014) gerçekleştirdikleri bir çalışmada tartışma forumlarının, çevrimiçi öğrenme süreçlerinde yaygın olarak kullanılmakta olan öğrenme yönetim sistemlerinin en çok kullanılan bileşeni olduğu sonucuna ulaşmışlardır. Bu bağlamda, eş zamansız iletişime olanak tanıyan yapısı sayesinde öğrenenlerin daha fazla etkileşime girebilmelerini sağlayan, öğrenenlerin kendi öğrenme hızlarına göre tartışmalara katılmalarını sağlayarak utangaç ve çekingen öğrenenlerin de tartışma süreçlerinde rol almalarına imkan tanıyan tartışma forumlarının (Da Silva, Barbosa ve Gomes, 2019; Kılınç, 2020) açık ve uzaktan öğrenme ortamlarında daha etkin bir şekilde kullanılabilmesi, öğrenme ortamlarının daha verimli olabilmesi açısından önem taşımaktadır. Verimli bir şekilde kullanılabilen bir çevrimiçi tartışma sürecinin, öğrenenlerin eleştirel düşünme becerilerine katkıda bulunduğu (Yang, 2008) göz önüne alındığında açık ve uzaktan öğrenme ortamlarında tartışma forumlarının kullanımına ilişkin olarak gerçekleştirilecek olan çalışmalara ihtiyaç duyulduğu ifade edilebilir. $\mathrm{Bu}$ durumun yanı sıra öğrenme ortamlarında biçimlendirme amaçlı değerlendirme aracı olarak kullanılabilmekte olan tartışma forumlarının, ölçme-değerlendirme süreçlerinde etkili bir şekilde kullanılabilmesine ilişkin çıkarımlarda bulunulacak olan bu çalışmanın alan yazına önemli katkılar sağlayacağı düşünülmektedir. 


\section{Çalışmanın Amacı}

$\mathrm{Bu}$ çalışma kapsamında çevrimiçi tartışma forumlarının açık ve uzaktan öğrenme ortamlarında etkili bir şekilde nasıl kullanılabileceğini belirlemek ve bir ölçme-değerlendirme kriteri olarak nasıl değerlendirilmesi gerektiğini ortaya çıkarmak amaçlanmıştır. Bu amaç kapsamında belirlenen araştırma soruları şu şekildedir:

- Çevrimiçi tartışma forumlarında öğrenenlerin katılım düzeyini artırmanın yolları neler olabilir?

- Çevrimiçi tartışma forumlarının tasarlanmasında hangi unsurlara dikkat edilmesi gerekmektedir?

- Çevrimiçi tartışma forumlarının öğrenme süreçlerinde hem öğrenenlere hem de öğreticilere olan katkısı nelerdir?

- Çevrimiçi tartışma forumlarının öğrenme ortamlarındaki sınırlılıkları nelerdir?

- Tartışma forumları, çevrimiçi öğrenme ortamlarında ölçme değerlendirme süreçlerine nasil entegre edilebilir?

\section{Yöntem}

\section{Araștırma Deseni}

Gerçekleştirilen bu çalışma kapsamında nitel araştırma yöntemlerinden biri olan durum çalışması deseni (case study) kullanılmıştır. Merriam (2013), durum çalışmasını sınırlı bir sistemin derinlemesine betimlenmesi ve incelenmesi olarak tanımlamaktadır. Yin (1984) ise durum çalışmasını; araştırmada "nasıl" ve "niçin" sorularına odaklanıldığında, araştırmacının olaylar üzerinde çok az ya da hiç kontrolünün olmadığında, olayın ya da olgunun kendi doğal yaşam çerçevesinde çalışıldığında ve olay ve gerçek yaşam arasındaki bağın yeterince açık olmadığı zamanlarda kullanılan bir araştırma yöntemi olarak tanımlamaktadır. Bununla birlikte durum çalışması deseninde, çoklu kaynakları içeren veri toplama araçları (gözlemler, görüşmeler, görsel-işitseller, doküman analizi, raporlar) da kullanılmaktadır (Creswell, 2007). Bu noktadan hareketle gerçekleştirilen bu araştırmada, çalışma konusu ile ilgili gerçekleştirilen uygulamaları içeren bir doküman analizi gerçekleştirilmiş, ardından açık ve uzaktan öğrenmede ölçme ve değerlendirme uygulamaları ile ilgili dikkat edilmesi gereken unsurların neler olması gerektiğine ilişkin alan uzmanlarının görüşlerine başvurulmuştur.

\section{Katılımcilar}

$\mathrm{Bu}$ çalışmada amaçlı örneklem seçim yöntemlerinden olan ölçüt örnekleme yöntemi tercih edilmiştir. Ölçüt örnekleme yöntemindeki temel anlayış, önceden belirlenmiş bir dizi 
ölçütü karşılayan bütün durumların çalışılmasıdır. Burada önceden hazırlanmış bir dizi ölçüt kullanılabileceği gibi ölçütler araştırmacı tarafından da geliştirilebilir (Yıldırım ve Şimşek, 2011). Gerçekleştirilen bu çalışma, açık ve uzaktan öğrenme alanı kapsamında ele alındığından dolayı, ölçüt olarak katılımcıların açık ve uzaktan öğrenme alanında uzman olmaları gözetilmiştir. $\mathrm{Bu}$ kapsamda gerçekleştirilen çalışmaya 9 alan uzmanı katkı sağlamıştır. Katılımcıların demografik bilgileri tablo 1. de gösterilmektedir.

\begin{tabular}{|c|c|c|}
\hline $\begin{array}{l}\text { Tablo } 1 \\
\text { Katılımcıların Demografik Özell }\end{array}$ & & \\
\hline Katılımcı (Takma Ad) & Yaş & Kıdem Yılı \\
\hline Masal & 35 & 12 \\
\hline Firat & 69 & 42 \\
\hline Esra & 56 & 36 \\
\hline Ali & 37 & 11 \\
\hline Okan & 34 & 7 \\
\hline Mustafa & 31 & 8 \\
\hline Tuna & 49 & 26 \\
\hline Şahin & 37 & 4 \\
\hline Feride & 49 & 27 \\
\hline
\end{tabular}

\section{Veri Toplama Aracı}

Durum çalışması deseninde temel veri toplama tekniği görüşmedir. Bu desende kullanılan görüşme tekniği, araştırmacılara etkileşim, esneklik ve alt sorular yoluyla irdeleme olanakları sunar (Yıldırım ve Şimşek, 2011). Bu bağlamda, gerçekleştirilen bu çalışma kapsamında verilerin elde edilmesi amacıyla beş sorudan oluşan yapılandırılmış görüşme formu kullanılmıştır. İçinde bulunduğumuz Kovid-19 pandemi şartlarından dolayı katılımcılardan çevrimiçi ortamda veri toplanması uygun görülmüştür. Bu bağlamda kullanılabilecek en uygun araçlardan birinin yapılandırılmış görüşme formu olduğu kararlaştırılmıştır. Yapılandırılmış görüşme formu, katılımcılardan detaylı bir şekilde görüş alabilmek için kullanılan en yaygın tekniklerden biridir (Büyüköztürk vd., 2014). Yapılandırılmış görüşme formu kapsamında hazırlanan araştırma soruları, üç alan uzmanının görüşleri doğrultusunda şekillendirilmiştir. $\mathrm{Bu}$ sayede araştırma sorularının kapsam geçerliğinin sağlanması amaçlanmıştır. Katılımcılara yönlendirilen araştırma soruları şu şekildedir:

- Çevrimiçi tartışma forumlarında öğrenenlerin katılım düzeyini artırmanın yolları neler olabilir? 
- Çevrimiçi tartışma forumlarının tasarlanmasında hangi unsurlara dikkat edilmesi gerekmektedir?

-Çevrimiçi tartışma forumlarının kullanılabilirliğini sağlamak için nelere dikkat edilmelidir?

- Çevrimiçi tartışma forumlarının öğrenme süreçlerinde hem öğrenenlere hem de öğreticilere olan katkısı nelerdir?

-Bu süreçte öğreticilerin ve öğrenenlerin rolleri neler olmalıdır?

- Çevrimiçi tartışma forumlarının öğrenme ortamlarındaki sınırlılıkları nelerdir?

- Tartışma forumları, çevrimiçi öğrenme ortamlarında ölçme değerlendirme süreçlerine nasil entegre edilebilir?

-Bu süreçte hangi noktalara dikkat edilmesi gerekir? Tartışma formundaki etkinlikler, ölçme değerlendirme kapsamında puanlanırken sınırlar neler olmalıdır? Bu durumun artıları ve eksileri neler olabilir?

\section{Veri Toplama Süreci ve Verilerin Analizi}

Veriler google formlar aracılı̆̆ı ile internet üzerinden toplanmıştır. İçinde bulunduğumuz Kovid-19 pandemi sürecinden dolayı yüz yüze görüşme yapmaktan ziyade çevrimiçi ortamda veri toplama tekniğini kullanmak tercih edilmiştir. Bu süreçte amaçli örnekleme yoluyla belirlenen katılımcılara yapılandırılmış görüşme formunun bağlantısı gönderilmiştir. Çalışmaya katılma konusunda gönüllü olan katılımcıların görüşleri bu yolla elde edilmiştir. Çevrimiçi veri toplama tekniğinin gönüllü katılımı artırdığı ve veri kaybını azalttığı göz önünde bulundurulduğunda (Kılınç ve Fırat, 2017), internet üzerinden veri toplamanın avantajlı yönlerinin olduğu ifade edilebilir.

Verilerin analizi sürecinde içerik analizi yönteminden faydalanılmıştır. İçerik analizinde temel amaç, toplanan verileri açıklayabilecek kavramlara ve ilişkilere ulaşmaktır. $\mathrm{Bu}$ amaçla toplanan verilerin önce kavramsallaştırılması, daha sonra da ortaya çıkan kavramlara göre mantıklı bir biçimde düzenlenmesi ve buna göre veriyi açıklayan temaların saptanması gerekmektedir (Yıldırım ve Şimşek, 2011). Çalışma kapsamında gerçekleştirilecek olan içerik analizi NVIVO 12 nitel veri analizi programı kullanılarak yapılmıştır. Görüşmelerden elde edilen ham verilerin içerik analizi sonucu kodlar belirlenmiştir. Gerçekleştirilen içerik analizleri, üç bağımsız araştırmacı tarafından gerçekleştirilmiş olup, analiz sonucunda elde edilen temaların sağlaması yapılmıştır. Araştırmanın güvenirliğini sağlamak için araştırmacılar arasındaki uyuma bakılmıştır. $\mathrm{Bu}$ doğrultuda Miles ve Huberman'ın (1994) “Görüş Birliği / (Görüş Birliği + Görüş Ayrılı̆̆ı) x 100” formülü kullanılmıştır. Buna göre araştırmacılar arasındaki güvenirlik \%90 olarak hesaplanmıştır. 


\section{Etik Konular}

Gerçekleştirilen bu çalışma kapsamında gönüllülük esası uygulanmıştır. Bu bağlamda çalışmaya katkı vermek isteyen uzmanlarla çalışılmıştır. Katılımcıların kimliklerinin gizlenmesi bağlamında çalışma grubu başlığı altında takma ad kullanılmıştır. Bunun yanı sıra Anadolu Üniversitesi Etik Kurulu tarafindan 03.11.2020 tarihinde protokol numaras1 55959 olan tarihinde etik kurul belgesi alınmıştır.

\section{Bulgular ve Yorumlar}

$\mathrm{Bu}$ başlık altında araştırma soruları kapsamında elde edilen bulgulara yer verilmiştir.

\section{Çevrimiçi Tartışma Forumlarında Katılımı Artıran Unsurlar}

Çalışma kapsamında belirlenen ilk araştırma sorusu, çevrimiçi tartışma forumlarında öğrenenlerin katılımını artıracak olan unsurların belirlenmesine yönelik olmuştur. $\mathrm{Bu}$ kapsamda alan uzmanlarına yönlendirilen araştırma sorusu bağlamında elde edilen görüşlerden yola çıkarak ulaşılan temalar şekil 1. de gösterilmektedir.

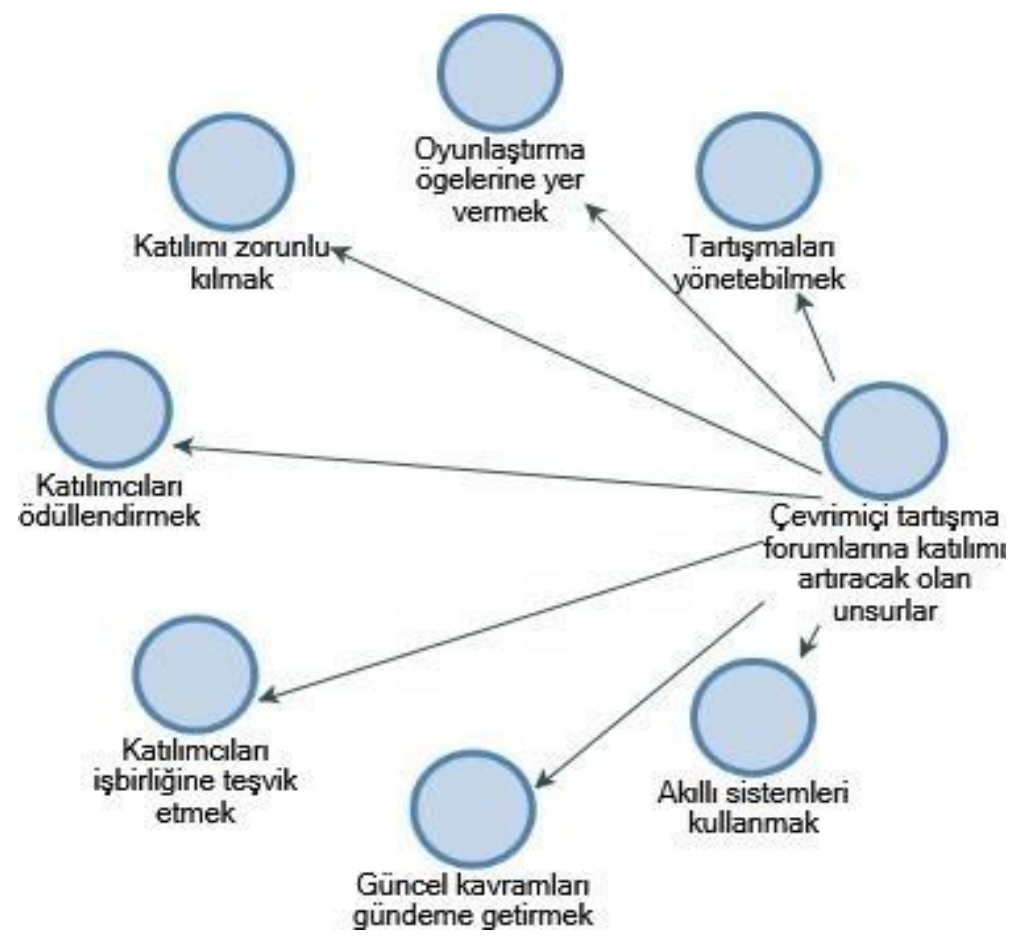

Şekil 1. Çevrimiçi tartışma forumlarında katılımı artıran unsurlar

Çevrimiçi tartışmalarda öğrenenlerin daha aktif bir şekilde yer almalarını sağlayabilme noktasında elde edilen görüşler incelendiğinde en çok vurgulanan unsurun, "oyunlaştırma ögelerine yer vermek" olduğu görülmüştür. Oyunlaştırma ögelerinin motivasyon artırıcı unsurlar olduğu (Sezgin ve Yüzer, 2020) göz önüne alındığında bu temanın, çevrimiçi 
tartışmalarda öğrenenlerin katılımı yönünde önemli olduğu ifade edilebilir. Tartışma forumlarındaki aktivitelerine göre öğrenenlere çeşitli rozetler tanımlamak, grubun en aktif katılımcıları listesi yayınlamak gibi unsurlar öğrenenleri tartışma sürecine katılma konusunda güdüleyebilir. Bu tema altında elde edilen görüşler şu şekildedir:

"Oyunlaştırma ögelerine yer verilebilir. Forumlarda rütbe tarzl işlevler mevcut. Ancak içeriğe uygun olarak farklı süreçler işe koşulabilir. Yalnızca rütbeyle olabilecek bir durum değil. Bu durumu Facebook da son zamanlarda gruplar için kullanıyor. Grubun en aktifini belirleme, en çok yanıt verenleri gösterme gibi özellikler kullanılabiliyor.” Ali

"Ögrenenin motivasyonunu artıracak etkinlikler düzenlenmeli. Oyunlaştırma ögeleri kullanilabilir. Onları küçük te olsa bir rekabet ortamına sokmak faydalı olabilir." Okan

"Ödüllendirme yapılmalıdır. Belki tartışma forumlarında en etkili cevap yazanlar ekstra bir puan ile ödüllendirilebilir.” Mustafa

“Öğreneni ikna etmek için, tartışma forumlarının ögrenene sağladığı katkıları vurgulayan bir küçük oyun bile tasarlanabilir." Feride

Çevrimiçi tartışma forumlarında katılımı artırabilecek unsurlar bağlamında katılımcılar tarafından en fazla vurgulanan temalardan bir diğeri ise "katılımcıları işbirliğine teşvik etmek" olmuştur. Tartışma forumlarını yöneten öğreticilerin öğrenenlere kılavuzluk yapması gerekmektedir (Kılınç, 2020). Bu kapsamda, çevrimiçi tartışma sürecinde öğreticilerin uygulayacağı tekniklerin, katılımın yüksek olması bağlamında önemli olduğu ifade edilebilir. Bu tema altında elde edilen görüşler şu şekildedir:

"Soru sormak, tartışma başlatmak gibi unsurlar katılımcıları işbirliğini teşvik edebilmek için oldukça önemlidir. Bu bağlamda, çevrimiçi tartışmaları yöneten ögreticilerin bu unsurlara dikkat etmesi gerekmektedir. " Furat

"Sorular ogrenenleri ogrenmeye hareket ettirecek şekilde provokatif hazırlanmalıdır.” Okan

“Öncelikle ögrreneni düşüncesini ifade etmeye alıştırmak gerekli. Bunu yapmak için de ögreneni ikna etmeliyiz." Feride

İlgili ana tema altında vurgulanan diğer bir bulgu ise "katılımcıları ödüllendirmek" teması olmuştur. Katılımcıları ödüllendirme konusunda, aktif katılan öğrenenlere ek puan verilmesi görüşü ölçme değerlendirme anlamında sorun yaratabilecek bir durum olarak değerlendirilebilir. Bu noktada bir süreç değerlendirmesi yapma gereksinimi ortaya çıkabilir. Bununla birlikte, tartışma süreci için fazladan emek harcayan öğrenenlerin ödüllendirilmesinin, katılımı artıracak bir unsur olduğu gerçeği de göz ardı edilmemelidir. Bu tema altında elde edilen görüşler şu şekildedir: 
"Ödüllendirme yapılmalıdır. Belki tartışma forumlarında en etkili cevap yazanlar ekstra bir puan ile ödüllendirilebilir." Okan

"Not vermek gibi ödüllendirmeler yapılabilir. Ancak bunun ölçme değerlendirme sürecine zarar verip vermeyeceği de tartışılmalıdır. Fazladan not vermek yerine tartışma forumlarının süreç değerlendirme yaklaşımında işe koşulması mümkün olabilir. ” Mustafa

Çevrimiçi tartışmalara katılımı artıracak unsurlardan bir diğeri de "akıllı sistemleri kullanmak" olarak belirtilmiştir. Buna göre, yapay zeka temelli akıllı sistemler işe koşularak tartışma sürecine yön verilebilir. Bu sayede öğrenci sayısı bakımından çok geniş kitlelere hitap eden çevrimiçi öğrenme ortamlarında gerçekleştirilen tartışmaların daha verimli olması sağlanabilir. Akıllı sistemler sayesinde daha verimli bir şekilde yönetilebilecek olan tartışmalarla birlikte öğrenenlerin sürece daha aktif bir şekilde katılım göstereceğini söylemek mümkündür. Bu tema altında elde edilen görüşler ise şu şekildedir:

"Çevrimiçi tartışma forumlarında teknoloji, pedagoji ve psikoloji tabanlı destek verebilecek akıllı sistemler de bulunmalıdır." Esra

"Çevrimiçi ortamlarda bulunan ögrenenlerin sayısal olarak fazla olduğu düşünüldü̈̆̈̈nde, bu ortamların her türlü yoğunluğa cevap verebilecek akıl sistemlerle desteklenmesi, tartışma sürecinden alınacak olan verimi artıracaktır." Tuna

Çevrimiçi ortamlarda gerçekleştirilen tartışma sürecinde katılımı artırmaya yönelik olarak elde edilen diğer temalar ise; Güncel kavramları gündeme getirmek, Katılımı zorunlu kılmak ve tartışmaları yönetebilmek olarak elde edilmiştir. Bu temalar altında elde edilen görüşler ise sırasıyla şu şekildedir:

“Yeni kavramlarl gündeme getirmek gerekmektedir.” Frrat

“Tartışmalara katılım zorunlu tutulabilir.” Ali

“Tartışma formunu kimin/kimlerin yöneteceği önemli olan başka bir konudur.” Esra

\section{Çevrimiçi Tartışma Forumlarının Tasarımı}

Çalışma kapsamında cevabı aranan ikinci araştırma sorusu çevrimiçi tartışma forumlarının tasarımında dikkat edilmesi gereken unsurların belirlenmesine yönelik olmuştur. $\mathrm{Bu}$ kapsamda alan uzmanlarına yönlendirilen araştırma sorusu bağlamında elde edilen görüşlerden yola çıkarak ulaşılan temalar şekil 2. de gösterilmektedir. 


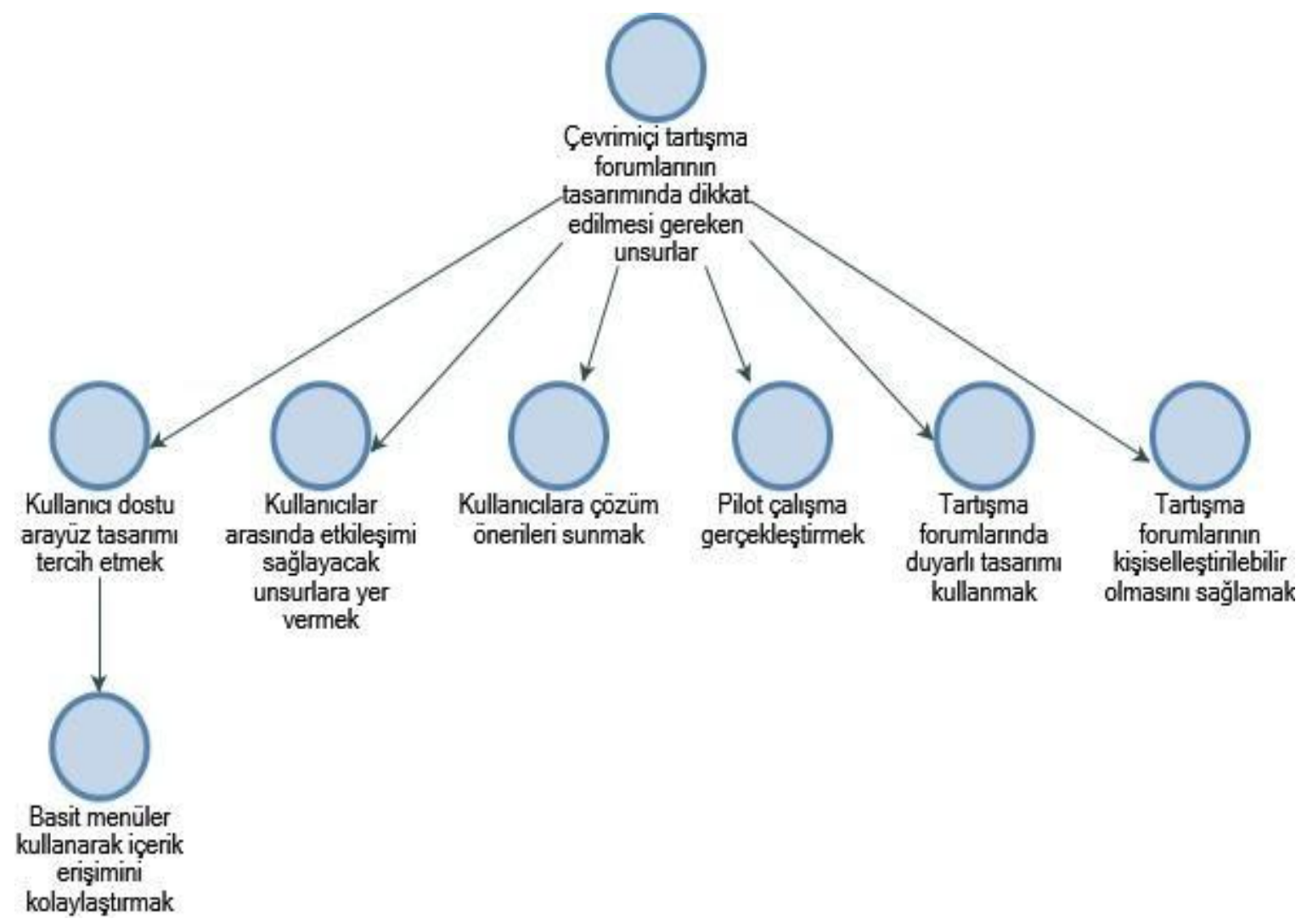

Şekil 2. Çevrimiçi tartışma forumlarının tasarımında dikkat edilmesi gereken unsurlar

$\mathrm{Bu}$ tema kapsamda katılımcilar tarafindan en fazla vurgulanan tema "Kullanıcı dostu arayüz tasarımı tercih etmek" teması olmuştur. Ayrıca bu temaya bağlı olarak "Basit menüler kullanarak içerik erişimini kolaylaştırmak" alt teması da elde edilmiştir. Bu kapsamda, çevrimiçi ortamlarda kullanılan tartışma forumlarının kolay kullanılabilir olması, katılımcıların isteklerine cevap verebilmesi önemli bir unsur olarak görülmektedir. Bu temalar altında elde edilen görüşler şu şekildedir:

"Sadece, basit ve hantal olmayan bir tasarım önemlidir. Bu aşamada teknolojinin kullanıcıya hizmet etmesi gerekir; kullanıcının teknolojiye değil." Esra

"Kullanılabilirlik açısından sade bir yapıda olması güzel bir durum olarak değerlendirilir." Ali

"İhtiyacın yalın, basit, anlaşılır ama ilgi çekici bir tasarım olduğu düşüncesindeyim." Feride

"Menü karmaşık olmamall, erişilebilirlik yüksek olmall, sade ve net yönlendirmeler olmalıdır.” Masal

İlgili ana tema altında vurgulanan diğer bir bulgu ise "Kullanıcılar arasında etkileşimi sağlayacak unsurlara yer vermek" teması olmuştur. Çevirmiçi öğrenme ortamlarında etkileşim 
sağlamanın temel unsurlardan biri olduğu (Mehall, 2020) düşünüldüğünde, etkileşime olanak tanıyan önemli araçlardan biri olan tartışma forumlarında da bu unsura yer verilmesinin önemli olduğu ifade edilebilir. Bu kapsamda elde edilen görüşler şunlardır:

"Beğen butonu olmall. Yanıtlar hiyerarşik şekilde verilecek şekilde tasarlanmal. Soru cevaplart herkes görebilmeli ancak yönetici tarafindan gizleme özelliği de olmall." Okan

"Gif ve emoji gibi özelliklerinin olması bireyin kendini ifade edebilmesi ve etkileşim sağlanması açısından önemlidir.” Mustafa

"Görsel tasarıma önem verilmeli ve etkileşim unsurlarına yer verilmelidir." Tuna

"Beğen butonu, etiketleme yapabilme, bildirim gönderilmesi gibi etkileşim sağlayacak unsurlara yer verilmelidir.” Esra

Tartışma forumlarının tasarımı bağlamında elde edilen diğer bir tema "Tartışma forumlarında duyarlı tasarımı kullanmak" teması olmuştur. Duyarlı (responsive) tasarımlar, kullanıcıların sahip oldukları akıllı telefonlar, tabletler, diz üstü bilgisayarlar gibi cihazların ekranlarıyla uyumlu bir şekilde çalışabilmektedir. Dolayısıyla öğrenenlerin tartışma süreçlerine daha verimli bir şekilde katılabilmeleri için duyarlı tasarımın kullanılması önemli bir unsur olarak görülebilir. Bu tema altında edilen görüşler şu şekildedir:

"Bu tasarımın Web bağlantısı olan bütün cihazlarda uyumlu ve sorunsuz çalışabilecek olması önemli bir noktadır.” Feride

"Öğrenenlerin tartışmalara daha fazla katılabilmesi için duyarlı tasarımlar büyük önem taşımaktadır.” Şahin

Tartışma forumlarının tasarımı konusunda katılımcılar tarafından ifade edilen diğer bir görüş ise "Tartışma forumlarının kişiselleştirilebilir olmasını sağlamak" teması altında toplanmıştır. Çevrimiçi öğrenme ortamlarında öğrenenlere her anlamda destek olmak gerekmektedir (Kumtepe vd., 2019). Sağlanacak olan bu desteklerden birinin de fiziksel olarak uzakta olan çevrimiçi öğrenenlere kişiselleştirilebilir öğrenme alanları sağlamak olduğu ifade edilebilir. Bu tema altında elde edilen görüşler şu şekildedir:

"Öğrenenin tartışma forumunu kişiselleştirmesine olanak sağlayacak seçenekler sunulabilir. Ortamı kendine göre özelleştirebilen öğrenen, kendi oluşturduğu bir ortamda sevdiği renkte, sevdiği yazı stilinde tartışma forumunda yer almaktan daha çok hoşnut olabilir." Feride

"Öğrenenlerin bu ortamları kendilerine göre düzenleyebilmesi, tartışma forumlarının kullanılabilirliğine olumlu anlamda katkı sağlayacaktır.” Masal 
Çevrimiçi tartışma forumlarının tasarımı bağlamında elde edilen diğer temalar şu şekildedir; Kullanıcılara çözüm önerileri sunmak, Pilot çalışma gerçekleştirmek. Bu temalar altında ifade edilen görüşler ise sırasıyla şu şekildedir:

"Kullanılabilirliği sağlamak için, Sıkça Sorulan Sorular (SSS) ya da bir Yardım Merkezi, her zaman en ince ayrıntısına kadar yaşanabilecek sorunlara yönelik çözüm yollarını sunmalıdır." Feride

"Tasarımın bütün web araçlarındaki prototiplerinin hedef kitlede yer alan gruplarla test edilmesi, gözden kaçan noktaların görünür hale gelmesine katkı sağlayabilir." Feride

\section{Çevrimiçi Tartışma Forumlarının Sağladığı Katkılar}

Çalışma kapsamında cevabı aranan diğer bir araştırma sorusu ise çevrimiçi tartışma forumlarının sağladığı katkıları belirlemek üzerine olmuştur. $\mathrm{Bu}$ bağlamda elde edilen görüşlerden yola çıkarak şekil 3. de gösterilen temalara ulaşılmıştır.

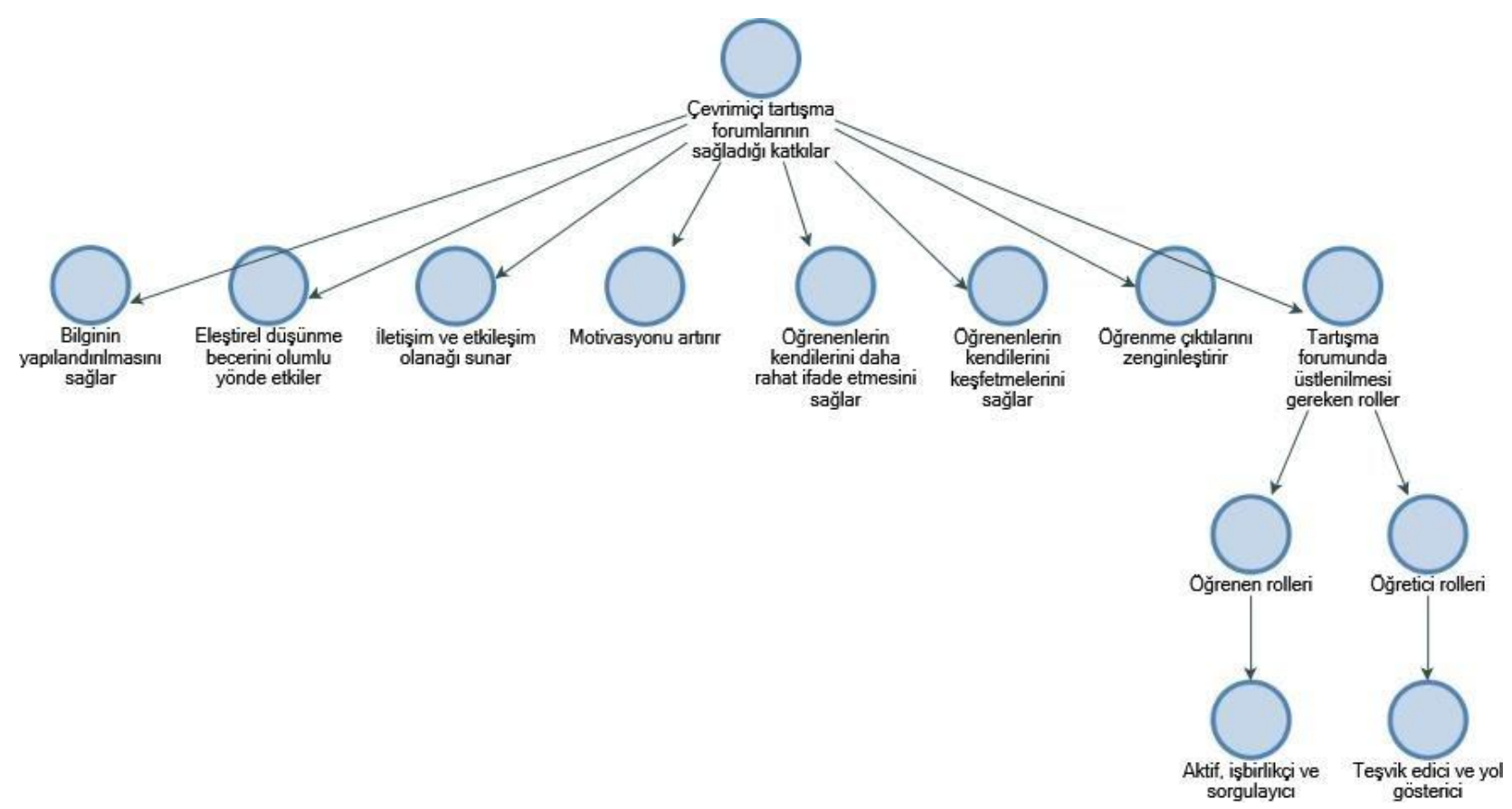

Şekil 3. Çevrimiçi tartışma forumlarının sağladığı katkılar

Çevrimiçi tartışma forumlarının sağladığı katkılar bağlamında katılımcıların en fazla vurguladığı tema "İletişim ve etkileşim olanağı sunar” olmuştur. Öğrenme ortamında bulunan öğrenenler ve öğreticiler ile fiziksel olarak aynı mekanda bulunamayan çevrimiçi öğrenenler, yalnızlık duygusu yaşayabilmektedir (Kaufmann ve Vallade, 2020). Yalnızlık duygusunu en aza indirebilmek için öğrenme süreçlerinin iletişim ve etkileşime olanak tanıması gerektiği 
söylenebilir. $\mathrm{Bu}$ kapsamda en çok tercih edilen araçlardan biri de çevrimiçi tartışma forumlarıdır (Almatrafi ve Johri, 2018). Bu tema altında elde edilen görüşler şu şekilde olmuştur:

"Tartışma forumları etkileşimi artırmaktadır ayrıca iletişim süreçlerini hızlandırmaktadır." Okan

“Öğrenme etkileşim ile gerçekleşir. Öğrenme süreci öğreticinin de öğrenme süreci olarak görülebilir. Etkileşim olmadan öğrenme söz konusu olmaz. Etkileşimin en çok yapıldiğı yerler tartışma forumlarıdır. ” Mustafa

İlgili ana tema altında elde edilen diğer bir tema ise "Bilginin yapılandırılmasını sağlar" teması olmuştur. Etkileşim ve iletişimin yoğun olarak yaşandığı tartışma forumlarında, öğrenenler kendi fikirleri dışında diğer fikirler ile de karşılaşmaktadır. Bu durum bakış açısının değişmesi, bilginin yapılandırılması gibi durumları da beraberinde getirmektedir. Bilginin yapılanmasını vurgulayan bu tema altında elde edilen görüşler şu şekildedir:

"Sosyal öğrenme anlayışı ile bilginin yapılandırılması tartışma forumlarında yapılmaktadır.” Mustafa

"Tartışma forumlarını öğrenenler için, öğrenen-öğrenen etkileşimiyle farklı bilgilere ve bakış açılarını keşfedebilecekleri bir keşif ve öğrenme alanı olarak değerlendiriyorum.” Feride

Çevrimiçi tartışma forumlarının sağladığı katkılar çerçevesinde elde edilen diğer bir tema "Öğrenme çıktılarını zenginleştirir" teması olmuştur. Tartışma forumlarının öğrenme çıktılarını zenginleştirmesi, diğer temalarda ulaşıldığ 1 gibi iletişim ve etkileşime olanak tanıması ve farklı bakış açılarına hakim olmayı sağlamasından kaynaklı bir durum olarak ortaya çıkmaktadır. Bu tema altında elde edilen görüşler şu şekildedir:

"Tartışma ortamları öğrenmeyi pekiştirir. Çünkü öğrenenler sorgular, ögreticiler de konunun pekişmesi için farklı sorularla ögrrenmeye katkı sunar." Ali

"Çevrimiçi tartışma forumları, ögrenenlerin öğrenme süreçlerinde kalma ve devam ettirme süreçlerinde motivasyon sağlamakta ve ögrenmelerini zenginleştirmektedir. Öğreticiler de verilen ögrenci yanıtlarından yeni şeyler ögrenmektedir. Karşılıklı bir öğrenme süreci gerçekleştirilmektedir.” Okan

İlgili ana tema altında elde edilen diğer temalar ise "Eleştirel düşünme becerini olumlu yönde etkiler", "Motivasyonu artırır”, “Öğrenenlerin kendilerini daha rahat ifade etmesini sağlar" ve "Öğrenenlerin kendilerini keşfetmelerini sağlar” şeklinde olmuştur. Bu temalar kapsamında elde edilen görüşler sırasıyla şu şekildedir:

"Çevrimiçi tartışma forumları, öğrenenlerin eleştirel düşünce gücünün artırllması için önemli bir kaynaktır.” Esra 
"Tartışma forumları, ögrenenlerin öğrenme süreçlerinde kalma ve devam ettirme süreçlerinde motivasyon sağlamakta ve ögrrenmelerini zenginleştirmektedir.” Okan

"Tartışma forumlarında öğrenenler kendini daha rahat ifade edebilir. Çünkü sınıf ortamında konuşurken arkadaşlarından ya da ögretmeninden çekinen ögrenenler olabilir. Bu durum ortadan kalkmış olur.” Ali

"Bu noktada ögrenenin keşfettiği sadece farklı bilgi ve bakış açıları değildir. Öğrenen kendisiyle ilgili yeterliliklerine ilişkin bir farkındalıktan yola çıkarak kendini keşfederek bir kimlik oluşturabilir. Bu bağlamda tartışma forumları öğrenenler için önemli bir keşif alanıdır." Feride

Bununla birlikte "Çevrimiçi tartışma forumlarının sağladığı katkılar" ana teması altında öğrenenlerin ve öğreticilerin tartışma forumlarında üstlenmesi gereken görevlerin neler olduğuna yönelik bir araştırma sorusu da katılımcılara yönlendirilmiştir. Bu kapsamda öğrenen rolleri bağlamında elde edilen tema "Aktif, işbirlikçi ve sorgulayıcı" teması olmuştur. Bu tema altında elde edilen görüşler şu şekildedir:

"Tartışma forumlarında ögrenenler aktif bir katılım sergileyerek fikirlerini açıkça belirtmelidir.” Mustafa

"Tartışma forumuna katılan öğrenenler, diğer öğrenenler ile işbirliği içinde olmalı ve sorgulayıc bir tavır sergilemelidir." Firat

Öğreticileri rolleri kapsamında ise ulaşılan tema “Teşvik edici ve yol gösterici” teması olmuştur. Bu tema altında elde edilen görüşler ise şu şekildedir:

“Öğreticiler tartışmayı yürütücü olmall, tartışmaya katılmayan öğrencilerin sebeplerini belirlemelidir. Bu doğrultuda öğrenenlerin tartışma sürecine katılımlarını teşvik edici önlemler almalıdır. ”Şahin

"Öğreticiler açısından tartışma forumlarının ögrenenlerin bilgi, görüs ve farkındalıklarına ilişkin farklılıklarını gözlemleyerek, öğrenenlerin ihtiyaç duyduklarl, eksikliğini hissettikleri noktalarda ögrenenlere kılavuzluk yapabilecekleri, ögrrenenlerin keşfetmelerine yönelik kolaylaştırıcı rolünü üstlenebilecekleri bir alan olduğu düşüncesindeyim." Feride 


\section{Çevrimiçi Tartışma Forumlarının Sınırlılıkları}

Çalışma kapsamında cevabı aranan diğer bir soru ise çevrimiçi tartışma forumlarının sınırlılıkları üzerine olmuştur. Bu doğrultuda elde edilen temalar şekil 4. de gösterilmektedir.

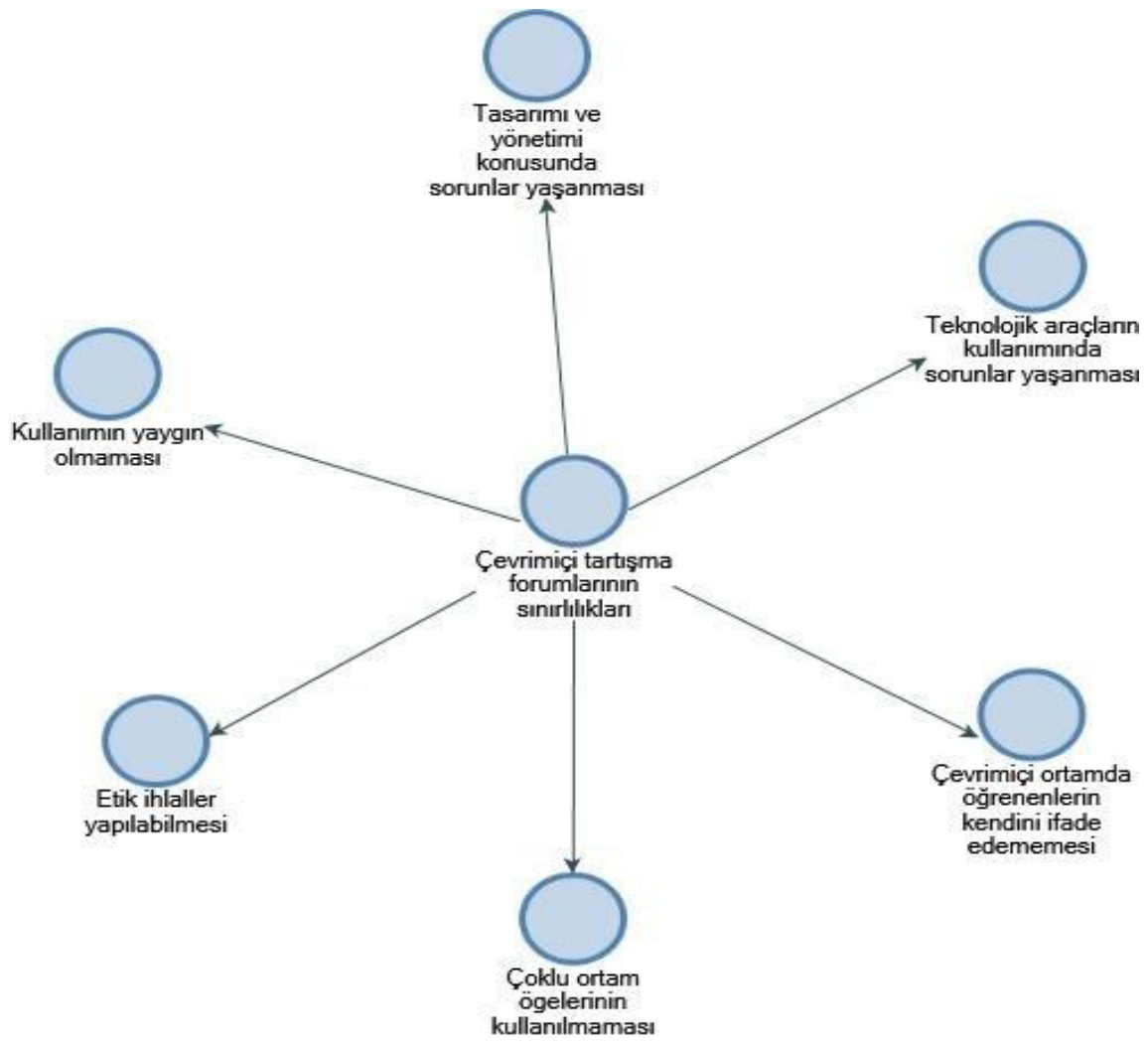

Şekil 4. Çevrimiçi tartışma forumlarının sınırlılıkları

Çevrimiçi tartışma forumlarının sınırlılıkları konusunda en fazla vurgulanan tema “Tasarımı ve yönetimi konusunda sorunlar yaşanması" teması olmuştur. Bu bağlamda özellikle geniş katılımcı kitlesine sahip öğrenen gruplarında, çevrimiçi tartışmaların yönetilebilmesinin, tartışma forumlarının amacına ulaşması noktasında önem taşıdığı (Kılınç, 2020) göz önüne alındığında, çevrimiçi tartışma forumlarının yönetilebilir bir yapıda olması gerektiği ifade edilebilir. Bu kapsamda tartışma forumlarının tasarımı aşamasında, kolay yönetilebilir bir şekilde tasarlanması gerektiği ifade edilebilir. Tartışma forumlarının tasarlanması ve yönetilebilmesi aşamalarında yaşanan sınırlılıklara ilişkin olarak alan uzmanlarından elde edilen görüşler şu şekildedir:

"Ortamın tasarlanması kullanılabilirliği doğrudan etkileyebilir. Dolayısıla tasarım aşamasının özenle düşünülmesi ve bu doğrultuda tartışma forumlarının işe koşulması gerekmektedir.” Masal 
"Görsel olarak statik olması etkileşim bakımından sinırlılık yaratmaktadır. Bazen tek yönlü bir etkileşim kanall gibi olabilmektedir.” Okan

"Görsellik olmaması (ki bu sağlanabilir), görsel iletişim tasarımına gerekli özenin gösterilmemesi önemli sintrlılıklardır.” Tuna

"Tartışma forumları katılımcı konumundaki öğrenenlerin bilgi eksikliği nedeniyle klsır döngüye girebilir ve istenen etkiyi yaratmayabilir. Bu nedenle, tartışma sürecinin yönetilebilmesi çok önemlidir. Bu aşamada gerek tartışmalara yön verecek alan uzmanları gerekse de akıllı sistemler kullanılmalıdır." Feride

Çevrimiçi tartışma forumlarının sınırlılıkları kapsamında ulaşılan diğer bir tema "Kullanımın yaygın olmaması" teması olmuştur. Bu bağlamda, çevrimiçi tartışma forumlarının çevrimiçi öğrenme ortamlarında sosyal bulunuşluk, aidiyet hissi gibi önemli unsurlarda olumlu bir etkiye sahip olduğu (Kılınç, 2020) unutulmamalıdır. Dolayısıyla çevrimiçi tartışma forumlarının daha sık kullanılması, öğrenenlerin tartışma forumlarına katkı sağlamaları için yönlendirilmesi, çevrimiçi öğrenme süreçlerinden daha fazla verim alınabilmesi açısından önem taşımaktadır. Bu tema altında elde edilen görüşler şu şekildedir:

"Öğrenenler çevrimiçi öğrenme ortamlarında yalnızca ders içeriklerine bakabiliyor, tartışma forumlarına bakmayabiliyorlar. Tartışma forumlarına katılım az olabiliyor." Ali

"Öğrenenler genelde tartışma forumlarına katılım sağlamayı gerekli görmezler. Bunun altında yatan nedenler ise, genelde ögrenenlerin konuyla ilgili yeterince bilgi sahibi olmaması, özgüven eksikliği, dersin notuna katkı sağlamadığı için zaman kaybu olarak algilanması olarak ifade edilebilir. " Feride

İlgili ana tema kapsamında ulaşılan diğer bir tema ise "Çevrimiçi ortamda öğrenenlerin kendini ifade edememesi” teması olmuştur. Bu noktada ilgili alan yazında farklı fikirlerin olduğu görülmektedir. Buna göre bazı kaynaklar (Alhaj ve Alwadai, 2021; Kılınç ve Altınpulluk, 2021; Mercimek ve Çaka, 2022) çevrimiçi tartışma forumları gibi eş zamansız öğrenme araçları sayesinde öğrenenlerin kendi hızında öğrenebildikleri, kendi hızında düşünebildikleri için kendilerini daha rahat ifade edebileceklerini belirtirken, bazı kaynaklar (Awofeso, 2018; Fei, 2021; Yang, Luo ve Sun, 2020) ise bunun tersine yüz yüze etkileşimde öğrenenlerin kendilerini daha rahat ifade edebileceklerini belirtmektedir. Bu tema altında elde edilen görüşler ise şu şekildedir:

"Asenkron iletişim transaksiyonel uzaklık kavramını beraberinde getirebilir. Başka bir ifadeyle, yüz yüze tartışma ortamlarında bireyler aynı anda aynı ortamda iken çevrimiçi ortamda mevcut olan fiziksel uzaklık ile birlikte kendilerini psikolojik olarak da uzak hissedebilir ve tartışma ortamına katkıda bulunamayabilirler." Masal 
"Çevrimiçi ortamlarda bazı öğrenenlerin kendilerini ifade edememesi, tartışma forumları özelinde de sorun yaratabilir. Ancak bu durumu genellemek mümkün değildir.” Esra

Çevrimiçi tartışma forumlarının sınırlılıkları teması kapsamında ulaşılan diğer temalar ise şunlardır; "Çoklu ortam ögelerinin kullanılmaması", "Etik ihlaller yapılabilmesi", “Teknolojik araçların kullanımında sorunlar yaşanması". Bu temalar kapsamında elde edilen görüşler sırasıyla şu şekildedir.

"Ses video resim gibi nesnelerin gönderilmesinde sorunlar yaşanabilmektedir. $\mathrm{Bu}$ sorunlar, ögrenenlerin ve ögreticilerin kendilerini ifade etmelerinde problemlere sebep olabilir." Mustafa

“Burada paylaşılan görüş ve fikirler bireylerin aleyhine kullanılabilir.” Esra

"Bunun ötesinde, teknoloji tabanl yaşanabilecek sorunlar bireyler arasinda, teknoloji sahipliği, okuryazarlığı ve kültürü açısından, ayrımcıllğa neden olabilir." Esra

Çalışma kapsamında belirlenen son araştırma sorusu ise Çevrimiçi tartışma forumlarının bir ölçme-değerlendirme aracı olarak kullanımına yönelik olmuştur. Bu kapsamda elde edilen temalar şekil 5. te gösterilmektedir.

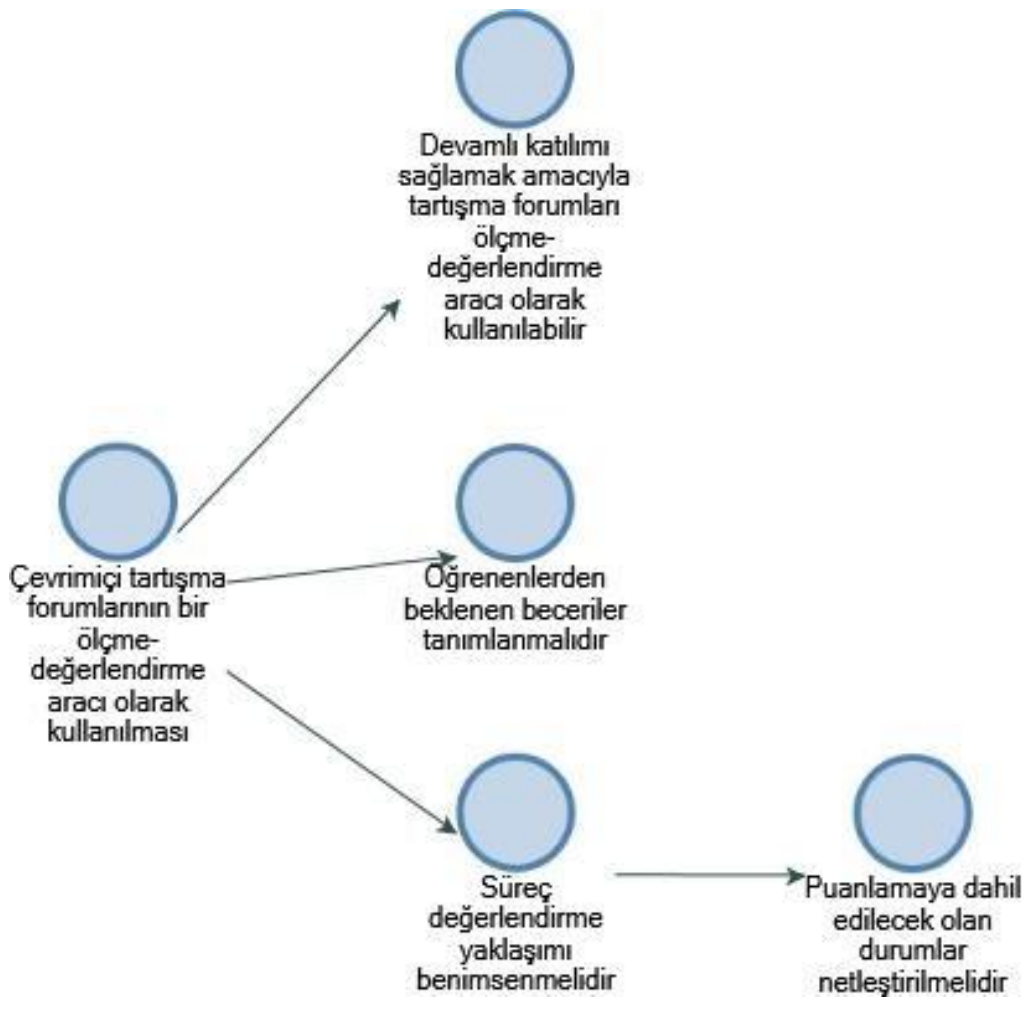

Şekil 5. Çevrimiçi tartışma forumlarının bir ölçme-değerlendirme aracı olarak kullanılması 
Çevrimiçi tartışma forumlarının ölçme-değerlendirme süreçlerine dahil edilebilmesine yönelik olarak en çok vurgulanan tema "Süreç değerlendirme yaklaşımı benimsenmelidir" teması olmuştur. Çevrimiçi öğrenme ortamlarında sonuç değerlendirmesi yapmak yerine süreç değerlendirilmesi yapmanın çevrimiçi öğrenme ortamlarında gerçekleştirilecek olan öğrenme etkinliklerine daha fazla anlam yüklenmesi, daha adil bir ölçme sisteminin uygulanması açısından önem arz eden bir konudur (Kılınç, Okur ve Usta, 2021). Bu bağlamda tartışma forumlarındaki aktivitelerin süreç değerlendirme yaklaşımına dahil edilmesi olumlu bir katkı sağlayacaktır. Süreç değerlendirme yaklaşımına yönelik olarak elde edilen görüşler şu şekildedir:

"Çevrimiçi tartışma forumlarında, süreç değerlendirme yaklaşımı benimsenmelidir." Esra

"Proje temelli öğrenme, e-Portföy oluşturma gibi süreç değerlendirme yaklaşımının benimseneceği alanlardan biri de çevrimiçi tartışma forumlarıdır." Firat

"Tartışma forumlarını yapılandırırken kısa yanıtlı tartışma sorularından kaçınmak gerekir. Sorgulamayı teşvik edici tartışmalar başlatılmalı ve bu tartışmalara katılım ölçme değerlendirme sürecinde dikkate alınmalıdır." Masal

"Bunun yanında ölçme-değerlendirme süreçlerinin bir amacı da biçimlendirmeye dönük durum belirlemedir (assessment for learning). Yani, değerlendirme sadece ögrencinin başarl düzeyine yönelik bir değer biçme işi değil, aynı zamanda ögrenme yaşantılarını iyileştiren, süreç temelli bir geri bildirim yöntemi olarak da görülmektedir. Bu açıdan tartışma forumlarında ögrenenlere verilecek geri bildirimlerin, ögrenme yaşantılarını iyileştirmek için katkı sunacă̆ı söylenebilir." Şahin

"Tartışma forumları çevrimiçi ortamlarda ölçme değerlendirme sürecinin bir parçası olarak kullanılabilir. Böylece sonuç odaklı bir yaklaşımın önüne geçmek ve süreç içinde öğrenene kendini iyi hissetmediği veya sıkıntılı bir zaman diliminde bulunduğu için başarısız olma ihtimali bertaraf edilebilir. ” Feride

Çevrimiçi tartışma forumlarının ölçme-değerlendirme sürecine dahil edilmesine ilişkin olarak elde edilen "Süreç değerlendirme yaklaşımı benimsenmelidir" temasının bir alt teması olarak ortaya çıkan bir başka tema ise "Puanlamaya dahil edilecek olan durumlar netleştirilmelidir" teması olmuştur. Bu noktada bir öğrenme aracının ölçme-değerlendirme süreçlerine dahil edilebilmesi için hangi kriterlerin gözetileceğinin belirlenmesinin ve bunun öğrenenlere duyurulmasının önem taşıdığı ifade edilebilir. Bu tema altında elde edilen görüşler şu şekildedir: 
"Tartışma forumlarına katılım bile puanlanabilir. Böylelikle ögrenilenlerin pekişmesi sağlanabilir. Ölçme değerlendirme için açık uçlu sorular sorulabilir. Bu sayede ögrenenlerin kendilerini ifade edebilmeleri să̆landiğ gibi kopya davranışı olmadan sürece katılmış olurlar. Çoktan seçmeli sorular da sorulabilir. Ancak kopya çekme davranışl göz önünde bulundurularak puan olarak az bir puan olması sağlanabilir." Ali

"Öğrenenlerin puanlarında etki edebilir. Özellikle aktif öğrenenlere ek puanlar verilebilir. En çok sistemde kalan ve zaman harcayan ögrenenlere değerlendirme süreçlerinde ayrıcalık verilebilir. En çok katılım gösteren ve en iyi cevapları veren ögrenenlere ödüllendirme yapılabilir." Okan

"Öğrencilerin tartışma formlarında kullandıkları ifadeler incelenebilir derse ilişkin yapılan yorumların yoğunlukları bakılarak derecelendirilebilir ve bu yöntemle puanlanabilir. Dersle ilgili olması, gerçekten değerli olması ve tartışmayla ilişkili olması olabilir. Aksi halde öğrenmeye hizmet etmeyen mesajlar olacaktır." Mustafa

“Öğrenenin gerçekten tartışmaya katılıp katılmadı̆̆ öğrenen tarafindan değerlendirilmelidir. Yoksa sadece sisteme girmek ve not almak için mi girdiği araştırlmalıdır?" Tuna

"Sadece katılımı özendirmek-teşvik etmek amacıyla tartışmalara katılımın puanlamaya hesapsizca dahil edilmesi, beklenmeyen durumlar yaratabilir. " Şahin

Çevrimiçi tartışma forumlarının ölçme-değerlendirme sürecine dahil edilmesine ilişkin olarak elde edilen diğer bir tema ise "Devamlı katılımı sağlamak amacıyla tartışma forumları ölçme-değerlendirme aracı olarak kullanılabilir" teması olmuştur. Süreç değerlendirme yaklaşımının belirleneceği bir çevrimiçi öğrenme sürecinde, öğrenenler tartışma forumlarına daha sık katılmak isteyebilirler. Bu durum tartışma forumlarının daha etkin bir şekilde kullanılabilmesine olanak tanıyacak bir unsur olarak değerlendirilebilir. Devamlı katılımı sağlamak amacıyla tartışma forumları ölçme-değerlendirme aracı olarak kullanılabilmesine yönelik temaya ilişkin elde edilen görüşler şu şekildedir:

"Çevrimiçi ögrrenme ortamlarına ögrenenlerin aktif bir şekilde katılımını sağlamak zorlayıcı olabilir. Katılımı sağlamak/desteklemek amacıyla tartışma forumların süreç değerlendirme yaklaşımıyla birlikte mutlaka kullanılması gerektiğini düşünüyorum. Böylece öğrenenler, kendileri dışında öğrenenler olduğunu, onlarla etkileşim kurabileceklerini ve ögrenme sürecinde onlara rehberlik yapabilecek bir ögreticinin varlı̆̆ını hissedebilirler. Bu da öğrenim sürecini destekler." Masal

"Süreç değerlendirmesi yaklaşımı tartışma forumlarının öğrenenin ihtiyacına uygun şekilde tartışmalara katılımıyla ders notuna katkı sağlayabileceği ve kendini ifade edebileceği bir alan olarak algilanmasina neden olabilir. Böylece ögrenen öğrenmede diğer öğrenenlerin paylaşımlarını okuyup, anlayı, analiz edip, değerlendirip, yeniden oluşturma yoluna gidebilir." Feride 
Çevrimiçi tartışma forumlarının ölçme-değerlendirme süreçlerinde işe koşulmasına yönelik olarak elde edilen son tema "Öğrenenlerden beklenen beceriler tanımlanmalıdır" teması olmuştur. Bu kapsamda çevrimiçi tartışma forumlarının etkin bir ölçme-değerlendirme aracı olarak kullanılması için, tartışma ortamlarında öğrenenlerden beklenenlerin açıkça ifade edilmesi gerektiği söylenebilir. Bu tema altında elde edilen görüş ise şu şekildedir:

"Ĕger bu ortamlara katılımda öğrenciden ortaya konması beklenen becerinin (konu hakkında ders içeriğine dayal eleştirel düşünme, analiz, vb. üst düzey düşünme becerileri için) tartışma forumlarında ortaya konulması mümkünse, yani ölçülecek özellik forumdaki tartışmalarda ortaya konulabilecekse, bu yöntem efektif olabilir." Şahin

\section{Tartışma, Sonuç ve Öneriler}

Çevrimiçi tartışma forumları, çevrimiçi öğrenme ortamlarında fiziksel olarak birbirinden ayrı olan öğrenenlerin iletişime ve etkileşime geçebilmelerine olanak tanıyan önemli bir öğrenme malzemesidir. Bu noktadan hareketle gerçekleştirilen bu çalışma kapsamında, çevrimiçi tartışma forumlarının etkin bir şekilde kullanılabilmesi ve ölçmedeğerlendirme süreçlerinde işe koşulabilmesi noktasında yapılması gerekenler üzerinde yoğunlaşılmıştır. Bu kapsamda vurgulanan en önemli noktalardan biri çevrimiçi tartışma sürecine katılımın artırılması olmuştur. Bu bağlamda ulaşılan sonuçlardan ilki oyunlaştırma ögelerinin kullanılması gerektiği olmuştur. Çevrimiçi tartışma sürecine katılım durumuna göre öğrenenlere rütbeler vermek, grubun en aktifleri listesi yayınlamak gibi oyunlaştırmaya yönelik unsurlar, öğrenenlerin tartışma sürecine katılım göstermeleri konusunda kendilerine bir motivasyon kaynağı sağlayabilir. Ulaşılan bu sonuç ile benzer olarak Ozcinar vd. (2021) ve Şahin vd. (2017) tarafından gerçekleştirilen çalışmalarda da, çevrimiçi öğrenme süreçlerinde oyunlaştırıcı ögeler kullanmanın öğrenenlerin süreçlere katılımları noktasından önem taşıdığ belirtilmektedir.

Çevrimiçi tartışma forumlarının etkin bir şekilde kullanılabilmesi için dikkat edilmesi gereken en önemli unsurlardan biri tartışmaların yönetilmesidir (Kılınç, 2020). Çevrimiçi tartışmaların yaşandığı tartışma forumlarının bir moderatör tarafindan yönetilebilmesi ve bu süreçte öğrenenlere kılavuzluk edilmesi önem taşımaktadır. $\mathrm{Bu}$ noktada, tartışmaları yönetenler bazen alan uzmanlarından oluşan öğreticiler olabilirken bazen de yapay zeka algoritmalarının işe kolulduğu akıllı sistemler de olabilmektedir. Bununla bağlantılı olarak bu çalışma kapsamında da akıllı sistemlerin kullanılması gerektiği sonucuna ulaşılmıştır. Tartışma forumlarında tartışmaların sürekli devam edebilmesi için tartışmaları yöneten öğreticilerin ya da akıllı sistemlerin sosyal yapılandırmacılık kuramı doğrultusunda hareket etmeleri gerektiğidir (Kılınç, 2020). Sosyal yapılandırmacı kuramda Vygotsky (1980) tarafından 
öğrenme için sosyal olarak zengin bir çevreye ihtiyaç olduğu ve bireyin daha deneyimli akranları ve yetişkinlerle çalışırken bilişsel fonksiyonlarının daha fazla geliştiği ifade edilmektedir. Bireyler arası etkileşimi önemseyen sosyal yapılandırmacı yaklaşım öğrenmede işbirliğinin oldukça büyük bir öneme sahip olduğunu vurgulamaktadır (Özdemir ve Yalın, 2007). Öğretme öğrenme süreci içerisinde anlamın yapılandırılması, sosyal bağlamda bireylerin bilgiyi birbirleriyle paylaşmalarıyla gerçekleşmektedir. Bu süreçte öğrenen, oluşturduğu anlamı paylaşarak diğer öğrenenlerin fikirlerini etkilemekte ve onların fikirlerinden de etkilenmektedir (Fer ve Cırık, 2007). Bu anlamda öğrenme ortamının da öğrenme ve etkileşim bağlamında bir sosyal topluluk haline getirilmesi oldukça önemli görülmektedir (Kalina ve Powell, 2009). Sosyal yapılandırmacı öğrenme ortamında öğrenenler, tıpkı gerçek hayatta olduğu gibi çevresindeki kişilerle sosyal etkileşimlere girmekte, onlarla konuşmakta, tartışmakta, paylaşmakta, işbirliği yapmakta ve diyaloglar kurmaktadırlar (Jaramillo, 1996; Jonassen, 1999). Dolayısıyla, çevrimiçi tartışma süreçlerinde sosyal yapılandırmacı kuramın gereklilikleri doğrultusunda hareket etmenin önemli bir unsur olduğu söylenebilir.

Çevrimiçi öğrenme ortamlarında işbirliğine dayalı bir şekilde öğrenme etkinliklerinin düzenlenebildiği çevrimiçi tartışma forumlarından alınacak olan verimi artırabilmek için dikkat edilmesi gereken unsurlardan biri de tartışma forumlarının tasarımıdır. $\mathrm{Bu}$ aşamada kullanıcı dostu bir tasarım gerçekleştirilmesi ve kullanımının yaygınlaşabilmesi için duyarlı (native) tasarımlar tercih edilmesi önemli bir gereklilik olarak ortaya çıkmıştır. Elde edilen bu sonuç Kumtepe vd. (2019) tarafından gerçekleştirilen çalışmanın sonuçları ile tutarlılık göstermektedir. Buna göre, çevrimiçi tartışma forumlarının kullanımının kolay olması ve erişilebilir olması gerekmektedir. Bu durumun yanı sıra tartışma sürecinde beğen butonu olması, gifler ve emojilerin kullanılabilmesi ve etiketleme yapılabilmesi, bu ortamların tasarımı açısından önem taşıyan diğer unsurlar olarak göze çarpmaktadır. Ayrıca öğrenenlerin tartışma forumlarını istedikleri renkte ve yazı tipinde kullanabilmesi gibi kişiselleştirme olanaklarına yer verilmesinin de tasarım açısından önemli görülen diğer bir unsur olduğu ifade edilebilir.

Çalışma kapsamında elde edilen diğer sonuçlar, çevrimiçi tartışma forumlarının sağladığı avantajlara yönelik olmuştur. Bu kapsamda tartışma forumlarının; iletişim ve etkileşim olanağı sunması, öğrenme çıktılarını zenginleştirmesi, eleştirel düşünme becerisine katkı sağlaması gibi önemli katkılar ön plana çıkmıştır. Bu durum, çevrimiçi öğrenme ortamlarında kullanılan tartışma forumlarının, öğrenenlerin gelişimleri açısından önemli bir öğrenme malzemesi olduğunu göstermektedir. Bu görüş ile benzer olarak, Hernández-Lara ve Serradell-López (2018) tarafından gerçekleştirilen çalışmada, çevrimiçi tartışma forumlarının daha kalıcı öğrenme süreçlerinin gerçekleştirilebilmesi açısından önem taşıdığ 1 vurgulanmıştır. 
Çevrimiçi tartışma forumlarının avantajların yanı sıra sahip olduğu sınırlılıklar da çalışma kapsamında değinilen başka bir konu olmuştur. Buna göre; tasarımı ve yönetimi konusunda sınırlılıklar yaşanması, kullanımının yaygın olmaması, bazı öğrenenlerin tartışma forumlarında kendilerini ifade edememeleri ve yine bazı öğrenenlerin teknolojik araçları kullanmada sorunlar yaşaması gibi konular vurgulanmıştır. Bu bağlamda değinilmesi gereken diğer bir durumun da dijital uçurum konusu olduğu ifade edilebilir. Buna göre her öğrenin eşit şartlarda teknolojik araçlara ve internet alt yapısına ulaşamaması, çevrimiçi tartışma forumlarınının kullanımı noktasında bir sınırlılık olarak değerlendirilebilir. Bu konu üzerine gerçekleştirilen bir çalışmada Yuhanna, Alexander ve Kachik (2020), iyi bir şekilde yönetilemeyen tartışma forumlarında öğrenenlerin devamlılık sağlamalarının zor olduğu ifade edilmiştir. Bununla birlikte tartışma sürecindeki etkinliklerin kontrol altına alınamaması, bazı öğrenenlerin uygunsuz içerikler paylaşması ve nefret söylemlerine yol açmasına zemin hazırlayabilmektedir (Alshamrani, 2019).

Çevrimiçi tartışma forumlarının ölçme-değerlendirme aracı olarak kullanılması noktasında ulaşılan en önemli sonuçlardan biri, süreç değerlendirmesi aşamasında tartışma forumlarında gösterilen etkinliklerin bir değerlendirme kriteri olarak benimsenebilecek olmasıdır. Bu bağlamda tartışma forumlarında öğrenenlerin tartışılan konulara sağladıkları katkılar, kendilerine bir değerlendirme notu olarak dönebilmelidir. Bu sayede öğrenme süreçlerinde gerçekleştirilen tartışma etkinliklerinin daha fazla önem kazanması mümkün olabilir. Öğrenenlerin, not alacaklarını bildikleri bir sürece daha aktif ve daha istekli bir şekilde katılabilmeleri de mümkün olabilir. Bu durum, daha zengin öğrenme çıktılarını da beraberinde getirecek bir unsur olarak değerlendirilebilir. Tartışma etkinliklerinin, süreç değerlendirme yaklaşımında kullanılabileceği Alhan ve Şimşek (2020) tarafından da vurgulanmaktadır. Çalışma kapsamında elde edilen diğer bir sonuç ise süreç değerlendirmesinde kullanılabilecek olan tartışma forumlarında puanlamaya dahil edilecek olan durumların belirlenmesi gerektiği olmuştur. $\mathrm{Bu}$ bağlamda bir derecelendirme ölçeğinin hazırlanarak öğrenenlere sunulması gerektiği ifade edilebilir. 


\section{Sınırlılıklar ve Öneriler}

Katılımcı olarak 9 alan uzmanı ile ve konu olarak çevrimiçi tartışma forumları ile sınırlı tutulan bu çalışma kapsamında elde edilen bulgulara dayalı olarak şu önerilerde bulunulmuştur:

Çevrimiçi tartışma forumlarında, rütbe vermek, en fazla katkı sağlayanları belirlemek gibi oyunlaştırıcı ögelere yer verilmesi, bu ortamlarında daha ilgi çekici olması için önemli bir nokta olarak görülmektedir. Bu sayede öğrenenlerin kendi içlerinde bir rekabete de girmeleri de sağlanabilir. Bu durum, aktif katılımın artmasını sağlayabilecek bir unsur olarak değerlendirilmektedir.

Çevrimiçi tartışma sürecini kontrol altına alabilmek ve bu süreci verimli bir şekilde yönetebilmek için özellikle de öğrenen sayısı 150'yi geçen kitlesel gruplar için akıllı sistemler işe koşulabilir. Bu sayede tartışmaların sürekliliği sağlanabilir.

Çevrimiçi tartışma forumlarının tasarım aşamasında kullanıcı dostu duyarlı tasarımlar seçilmelidir. Bu noktada insan-bilgisayar etkileşimi disiplininden faydalanılabilir. Bunun yanı sira beğenme butonu, etiketleme yapma gibi etkileşime olanak sağlayacak unsurlar da işe koşulmalıdır.

Çevrimiçi öğrenme süreçlerinde işe koşulabilecek ölçme-değerlendirme yaklaşımlarından biri olan süreç değerlendirme yaklaşımının benimsendiği öğrenme ortamlarında, çevrimiçi tartışma forumlarında gerçekleştirilen etkinliklerin de puanlanması gerekmektedir. $\mathrm{Bu}$ sayede çevrimiçi tartışma forumlarına gösterilen ilginin artacağ düşünülmektedir. 


\section{Kaynakça}

Alhaj, A. A. M. \& Alwadai, M. A. M. (2021). Utilizing Online Discussion Forums to Improve Graduate Students' Cognitive Skills at King Khalid University: The University Faculty's Perspectives. Language \& Translation, 9(3), 15-23.

Alhan, S. S. ve Şimşek, Ü. (2020). Fen Bilimleri Öğretmen Adaylarının Teknolojik Pedagojik Alan Bilgileri Üzerine Harmanlanmış Öğrenme Ortamının Etkisi: Özel Öğretim Yöntemleri-II. Kastamonu Eğitim Dergisi, 28(6), 2305-2318. Doi: 10.24106/kefdergi.704381

Almatrafi, O. \& Johri, A. (2018). Systematic review of discussion forums in massive open online courses (MOOCs). IEEE Transactions on Learning Technologies, 12(3), 413428. Doi: 10.1109/TLT.2018.2859304

Alshamrani, M. (2019). An Investigation of the Advantages and Disadvantages of Online Education, Doctoral dissertation, Auckland University of Technology.

Awofeso, N. (2018). Utilizing Question and Answer Discussion Forums to Enhance Learning in University Health Courses: Q\&A Online Discussion Forums for Efficient ELearning. C.N. Stevenson (Ed.), Enhancing Education Through Open Degree Programs and Prior Learning Assessment içinde (ss. 235-251). IGI Global.

Black, L. W., Wesler, H. T., Cosley, D. \& DeGroot, J. M. (2011). Self-governance through group discussion in Wikipedia: Measuring deliberation in online groups. Small Group Research, 42(5), 595-634. Doi: 10.1177/1046496411406137

Büyüköztürk, Ş., Kılıç Çakmak, E., Akgün, Ö. E., Karadeniz, Ş. ve Demirel, F. (2014). Bilimsel araştırma yöntemleri. Ankara: Pegem.

Chaudhary, S.V.S. \& Dey, N. (2013). Assessment in open and distance learning system (ODL): A challenge. Open Praxis, 5(3), 207-216.

Chen, F. C. \& Wang, T. C. (2009). Social conversation and effective discussion in online group learning. Educational Technology Research and Development, 57(5), 587-612. Doi: 10.1007/s11423-009-9121-1

Creswell, J. W. (2007). Qualitative inquiry \& research design: Choosing among five approaches (2rd ed.). USA: SAGE Publications.

Da Silva, L. F. C., Barbosa, M. W. \& Gomes, R. R. (2019). Measuring participation in distance education online discussion forums using social network analysis. Journal of the Association for Information Science and Technology, 70(2), 140-150. Doi: 10.1002/asi.24080 
de Lima, D. P., Gerosa, M. A., Conte, T. U. \& Netto, J. F. D. M. (2019). What to expect, and how to improve online discussion forums: the instructors' perspective. Journal of Internet Services and Applications, 10(1), 1-15. Doi: 10.1186/s13174-019-0120-0

Fei, Q. (2021). Noise from online discussion forums: Evidence from IPOs in China. China Journal of Accounting Research, 14(3). 231-255. Doi: 10.1016/j.cjar.2021.05.001

Fer, S. ve Cırık, İ. (2007). Yapılandırmacı öğrenme: Kuramdan uygulamaya. İstanbul: Morpa Yayınlar1

Gerosa, M. A., Filippo, D., Pimentel, M., Fuks, H. \& Lucena, C. J. P. (2010). Is the unfolding of the group discussion off-pattern? Improving coordination support in educational forums using mobile devices. Computers \& Education, 54(2), 528-544. Doi: 10.1016/j.compedu.2009.09.004.

Gilbert, P. K. \& Dabbagh, N. (2005). How to structure online discussions for meaningful discourse: A case study. British Journal of Educational Technology, 36(1), 5-18. Doi: 10.1111/j.1467-8535.2005.00434.x

Green, R. A., Farchione, D., Hughes, D. L. \& Chan, S. P. (2014). Participation in asynchronous online discussion forums does improve student learning of gross anatomy. Anatomical sciences education, 7(1), 71-76. Doi: 10.1002/ase.1376

Hampton, D., Pearce, P. F. \& Moser, D. K. (2017). Preferred methods of learning for nursing students in an online degree program. Journal of Professional Nursing, 33(1), 27-37. Doi: 10.1016/j.profnurs.2016.08.004

Hernández-Lara, A. B. \& Serradell-López, E. (2018). Student interactions in online discussion forums: their perception on learning with business simulation games. Behaviour \& Information Technology, 37(4), 419-429. Doi: 10.1080/0144929X.2018.1534715

Hew, K. F. \& Cheung, W. S. (2008). Attracting student participation in asynchronous online discussions: A case study of peer facilitation. Computers \& Education, 51(3), 11111124. Doi: 10.1016/j.compedu.2007.11.002

Hrastinski, S. (2006). The relationship between adopting a synchronous medium and participation in online group work: An explorative study. Interactive Learning Environments, 14(2), 137-152. Doi: 10.1080/10494820600800240

Jonassen, D. H., Davidson, M., Collins, M., Campbell, J. \& B. B. Haag. (1995) Constructivism and computermediated communication in distance education. The American Journal of Distance Education, 9(2), 7-26. Doi: 10.1080/08923649509526885

Kalelioğlu, F. ve Deryakulu, D. (2011). Çevrimiçi tartışma yapısının öğretmen adaylarının eleştirel düşünme eğilimleri ile gerçek ve yansıyan eleştirel düşünme performanslarına etkisi. Yayımlanmamış Doktora Tezi, Ankara Üniversitesi, Ankara. 
Kalina, C. \& Powell, K. C. (2009). Cognitive and social constructivism: Developing tools for an effective classroom. Education, 130(2), 241-250.

Karadağ, N. (2016). Açık ve uzaktan eğitimde ölçme ve değerlendirme: Mega üniversitelerdeki uygulamalar. Yayınlanmamış Doktora Tezi, Anadolu Üniversitesi Sosyal Bilimler Enstitüsü, Eskişehir.

Kaufmann, R. \& Vallade, J. I. (2020). Exploring connections in the online learning environment: student perceptions of rapport, climate, and loneliness. Interactive Learning Environments, 28(6). 1-15. Doi: 10.1080/10494820.2020.1749670

Kılınç, H. (2020). Çevrimiçi Grup Tartışmalarının Öğrenenler Üzerindeki Etkisinin Çeşitli Değişkenler Açısından Incelenmesi: Anadolu Üniversitesi Açıköğretim Fakültesi Örneği. Doktora Tezi, Anadolu Üniversitesi, Sosyal Bilimler Enstitüsü, Eskişehir.

Kılınç, H. ve Altınpulluk, H. (2021). Discussion Forums as a Learning Material in Higher Education Institutions. International Journal of Higher Education Pedagogies, 2(1), 19. Doi: 10.33422/ijhep.v2i1.25

Kılınç, H., \& Fırat, M. (2017). Opinions of expert academicians on online data collection and voluntary participation in social sciences research. Educational Sciences: Theory \& Practice, 17(5), 1461-1486. Doi: 10.12738/estp.2017.5.0261

Kılınç, H., Okur, M. R. ve Usta, İ. (2021). The Opinions of Field Experts on Online Test Applications and Test Security During the COVID-19 Pandemic. International Journal of Assessment Tools in Education, 8(4), 975-990. Doi: 10.21449/ijate.875293

Knowlton, D. S. (2002). Promoting liberal arts thinking through online discussion: A practical application and its theoretical basis. Educational Technology \& Society, 5(3), 189-194.

Kumtepe, E. G., Toprak, E., Öztürk, A., Tuna Büyükköse, G., Kılınç, H. ve Menderis, İ. A. (2019). Açık ve uzaktan öğrenmede destek hizmetleri: Yerelden küresele bir model önerisi. Açıöğretim Uygulamaları ve Araştırmaları Dergisi, 5(3), 41-80.

Loncar, M., Barrett, N. E. \& Liu, G. Z. (2014). Towards the refinement of forum and asynchronous online discussion in educational contexts worldwide: Trends and investigative approaches within a dominant research paradigm. Computers \& Education, 73(2014), 93-110. Doi: 10.1016/j.compedu.2013.12.007

Lyons, T. \& Evans, M. M. (2013). Blended learning to increase student satisfaction: An exploratory study. Internet Reference Services Quarterly, 18(1), 43-53. Doi: $10.1080 / 10875301.2013 .800626$

Mehall, S. (2020). Purposeful Interpersonal Interaction in Online Learning: What Is It and How Is It Measured?. Online Learning, 24(1), 182-204. Doi: 10.24059/olj.v24i1.2002 
Mercimek, B. \& Çaka, C. (2022). Asynchronous Environments in Online Courses: Advantages, Limitations, and Recommendations. G. Durak ve S. Çankaya (Eds.) In Handbook of Research on Managing and Designing Online Courses in Synchronous and Asynchronous Environments (pp. 96-116). IGI Global.

Merriam, S. B. (2013). Nitel araştırma: Desen ve uygulama için bir rehber (3. Baskıdan Çeviri, Çeviri Editörü: S. Turan). Ankara: Nobel Yayın Dağıtım.

Miles, M. B \& Huberman, A. M. (1994). Qualitative Data Analysis. London: Sage Publication.

Ozcinar, Z., Orekhovskaya, N., Svintsova, M., Panov, E., Zamaraeva, E. \& Khuziakhmetov, A. (2021). University Students' Views on the Application of Gamification in Distance Education. International Journal of Emerging Technologies in Learning, 16(19), 4-15. Doi: 10.3991/ijet.v16i19.26019

Özdemir, S. ve Yalın, A. İ. (2007). Web Tabanlı Asenkron Öğrenme Ortamında Bireysel ve İşbirlikli Problem Temelli Öğrenmenin Eleştirel Düşünme Becerilerine Etkileri. Ahi Evran Üniversitesi Kırşehir Ĕ̈itim Fakültesi Dergisi, 8(1), 79-94.

Schiek, D. \& Ullrich, C. G. (2019). Using Web Forums for Qualitative Inquiries: Empirical Findings on the Conditions and Techniques for Asynchronous Online Group Discussions. The Qualitative Report, 24(13), 5-16.

Sezgin, S. \& Yüzer, T. V. (2020). Analysing adaptive gamification design principles for online courses. Behaviour \& Information Technology, 39(10), 1-17. Doi: 10.1080/0144929X.2020.1817559

So, H. J. (2009). When groups decide to use asynchronous online discussions: collaborative learning and social presence under a voluntary participation structure. Journal of Computer Assisted Learning, 25(2), 143-160. Doi: 10.1111/j.1365-2729.2008.00293.x

Şahin, Y. L., Karadağ, N., Bozkurt, A., Doğan, E., Kılınç, H, Uğur, S., ... ve Güler, C. (2017). The use of gamification in distance education: A web-based gamified quiz application. Turkish Online Journal of Qualitative Inquiry, 8(4), 372-395. Doi: 10.17569/tojqi.329742

van Alten, D. C., Phielix, C., Janssen, J. \& Kester, L. (2019). Effects of flipping the classroom on learning outcomes and satisfaction: A meta-analysis. Educational Research Review, 28(2019), 1-18. Doi: 10.1016/j.edurev.2019.05.003

Vygotsky, L. S. (1967). Play and its role in the mental development of the child. Soviet Psychology, 5(3), 6-18.

Vygotsky, L. S. (1980). Mind in society: The development of higher psychological processes. Harvard university press. 
Yang, T., Luo, H. \& Sun, D. (2020). Investigating the combined effects of group size and group composition in online discussion. Active Learning in Higher Education, 1-14. Doi: $10.1177 / 1469787420938524$

Yang, Y. C. (2008). A Catalyst for Teaching Critical Thinking in a Large University Class in Taiwan: Asynchronous Online Discussions with the Facilitation of Teaching Assistants. Education Technology Research and Development, 56(2008), 241-264. Doi: $10.1007 / \mathrm{s} 11423-007-9054-5$

Yıldırım, A. ve Şimşek, H. (2011). Sosyal Bilimlerde Nitel Araştırma Yöntemleri (8. Baskı). Ankara: Seçkin Yayınları.

Yin, R. (1984). Case study research: design and methods (3rd ed.). California: Sage Publications.

Yuhanna, I., Alexander, A. \& Kachik, A. (2020). Advantages and disadvantages of Online Learning. Journal Educational Verkenning, 1(2), 13-19. 


\section{Yazar Hakkında}

\section{Arş. Gör. Dr. Hakan KILINÇ}

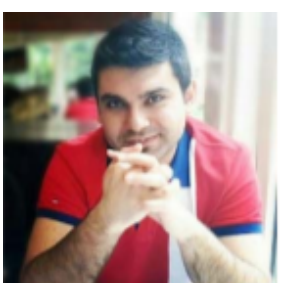

Anadolu Üniversitesi Açıköğretim Fakültesi Uzaktan Eğitim Bölümü'nde araştırma görevlisi doktor olarak çalışmaktadır. 2013 yılında Anadolu Üniversitesi Bilgisayar ve Öğretim Teknolojileri Öğretmenliği lisans eğitimini tamamlamıştır. Yüksek lisans ve doktora eğitimlerini ise sırasıyla 2016 ve 2020 yıllarında tamamlamıştır. Öğrenme teknolojileri, mobil öğrenme, dijital öyküleme, çevrimiçi veri toplama, sosyal ağ analizi, içerik üreten öğrenenler, çevrimiçi tartışma forumları, öğrenen motivasyonu, destek hizmetleri, öğrenenlerin sistemi bırakma davranışları alanlarında çalışmalar yapmıştır.

Tel (İş): Eposta:

URL:
+9022233505 80/2773

hakankilinc@anadolu.edu.tr https://www.researchgate.net/profile/Hakan-Kilinc https://scholar.google.com.tr/citations?user=Bucpce0AAAAJ\&hl=tr https://akademik.anadolu.edu.tr/hakankilinc/ogrenim-bilgisi 